\title{
The Road Not Taken: Failure to Protect from Atrocity Crimes in Myanmar
}

\author{
Malina Greta Meret Gepp* \\ DOI: $10.21827 /$ GroJIL.9.1.78-100
}

\section{Keywords}

R2P; MYANMAR; ATROCITY CRIMES

\begin{abstract}
In 2005, more than 150 heads of State and government pledged that the world must never witness another Rwanda. They accepted the Responsibility to Protect (R2P) both their own populations, and those of other States from atrocity crimes. Yet, in late August 2017, thousands of Rohingya had to flee from the alleged genocide taking place in their home, northern Rakhine in Myanmar. The international community, equipped with a toolbox developed and refined over the past 12 years, does nothing more than politely asking Myanmar to stop. This begs the question: to what extent can the Responsibility to Protect doctrine be used to save the Rohingya from atrocities committed against them? This article explores the potential application of the R2P in the context of Myanmar by exploring the root causes of the alleged genocide, the legal status of the R2P and various options open to the international community to protect the Rohingya. The case is made that applying the $\mathrm{R} 2 \mathrm{P}$ - in its current shape and form - would be in the best interest of the Rohingya. After all, the international community cannot stand by in the wake of another mass atrocity.
\end{abstract}

\section{Introduction}

'The situation [in Myanmar] seems a textbook example of ethnic cleansing'. ${ }^{1}$ These were the words of Zeid Al Hussein, former United Nations High Commissioner for Human Rights, when addressing the United Nations Human Rights Council (HRC) on 11 September 2017, two weeks after the atrocity crimes against the Rohingya minority in northern Rakhine began. ${ }^{2}$ Yet, at the time of writing, the international community has taken too little effective action to save the Rohingya minority in northern Rakhine, Myanmar. This is evidenced by the growing number of refugees in Bangladesh's refugee camps, as well as the HRC's assessment of the situation as having deteriorated for the Rohingya. ${ }^{3}$

\footnotetext{
Malina Gepp graduated Cum Laude from the University of Groningen with an LLB in International and European Law in July 2020. After working as a Human Rights Officer in Geneva for a year, she is currently an LLM Candidate at Columbia Law School in New York. Her areas of interest include Human Rights Law, Public International Law and Diplomacy. She can be contacted via e-mail at: gepp.malina@gmail.com.

1 Zeid Ra'ad Al Hussein, 'Opening Statement at the Human Rights Council 36th session' (OHCHR 11 September 2017).

2 ibid; OHCHR 'Report of the Detailed Findings of the Independent International Fact-Finding Mission on Myanmar' (17 September 2018) UN Doc A/HRC/39/CRP2 (IIFFMM Report) 177-178.

3 OHCHR 'Detailed Findings of the Independent International Fact-Finding Mission on Myanmar' (16 September 2019) UN Doc A/HRC/42/CPR5 (IIFFMM Follow-up Report) [176]; OCHA, 'Rohingya Refugee Crisis' $(O C H A)<$ https://www.unocha.org/rohingya-refugee-crisis> accessed 20 April 2020; UN Special Rapporteur Yanghee Lee, 'Myanmar: "Possible War Crimes and Crimes Against Humanity Ongoing in Rakhine and Chin States"' (29 April 2020) OHCHR Press Release.
} 
The Responsibility to Protect as adopted by the United Nations General Assembly (GA) in 2005 would serve as the ideal framework for a response. ${ }^{4}$ It declares a State's primary Responsibility to Protect its own population from war crimes, ethnic cleansing, crimes against humanity, and genocide. ${ }^{5}$ When a State is unable to do so, it may request assistance from others and only if it fails in its own responsibility, should the international community intervene. ${ }^{6}$ In such a case the international community has a responsibility to take timely and decisive action in accordance with the Charter of the United Nations (UN Charter) ${ }^{7}$, either under Chapter VI or VIII, or should these prove inadequate, the United Nations Security Council (SC) shall take collective action under Chapter VII. ${ }^{8}$ This structure, in particular to the international community's responsibility to react, seems to have been overlooked in the context of Myanmar.

This article investigates the reasons for the international community's inaction and offers suggestions on how to utilize the R2P. It will answer the question: to what extent can the Responsibility to Protect doctrine be used to save the Rohingya from atrocities committed against them? In doing so, events leading up to the 2017 attacks, the atrocity crimes that took place and the international response will be analysed. Post that the legal status of the R2P and its scope of application will be determined. Subsequently, the options to act before the international community will be addressed and their effectiveness weighed. Finally, an actionable solution is sought, by recognizing the R2P's limitations and defining measures that could realistically be adopted.

This research is crucial in ensuring 'never again' does not lose its meaning, in proving that there is a way to react to these atrocities and the international community can and should do so now. By adopting a realistic approach, the paper almost serves as a practical guide for the international community to protect the Rohingya. For this, the author has drawn on teleological interpretations of R2P documents, to assert that it is intended for situations like Myanmar. She further analysed voting patterns and arguments put forward by the veto powers (P5) of the SC to determine the scope of the doctrine. Moreover, by considering State practice and opinio juris, its soft law status could be determined. Drawing upon these preliminary conclusions thereafter allowed the determination of how the international community could react and identify the most realistic measures to do so under the $\mathrm{R} 2 \mathrm{P}$ framework.

\section{Historical Background and Analysis of the Current Situation}

The crimes against the Rohingya did not take place in a vacuum. Rather, they are the culmination of events that had built up for almost two centuries. This protracted institutionalization of hatred and 'othering' saw its height in the events taking place on 25 August 2017. ${ }^{9}$ Myanmar's security forces committed the most heinous crimes against the Rohingya Muslim minority in northern Rakhine State in the West of Myanmar (formerly

UNGA Res 60/1 (24 October 2005) UN Doc A/RES/60/1 2005 World Summit Outcome (WSOD) [138]-[139].

5 ibid; UNGA 'Report of the Secretary-General 63/677' (12 January 2009) Session? UN Doc A/63/677 [11], [49].

ibid.

7 Charter of the United Nations (signed 26 June 1945, published 24 October 1945, ratified 31 August 1965) 1 UNTS XVI (hereinafter UN Charter).

8 ibid.

9 Kyaw Zeyar Win, 'Securitization of the Rohingya in Myanmar' in Justine Chambers and others (eds), Myanmar Transformed? People, Places and Politics (ISEAS Yusof Ishak Institute 2018) 257-258, 270. 
known as Burma). ${ }^{10}$ Since then, the situation for the Rohingya who had not yet fled to Bangladesh only deteriorated. ${ }^{11}$

\section{A. A Roadmap to Atrocities}

Myanmar's Buddhist majority believes the Rohingya to be illegal immigrants from Bangladesh who came to Rakhine (formerly known as Arakan) during the British Colonial Empire (1824-1948). ${ }^{12}$ They are viewed as fundamentally different from other groups in Myanmar in terms of ethnicity, religion, and political identity which is referred to as 'othering' ${ }^{13}$ In 1948 and 1978, the Rohingya were formally classified as illegal immigrants and had to flee the country to neighbouring Bangladesh due to eruptions of violence between the State and the minority. ${ }^{14}$ The process of othering was expanded through the 1982 Citizenship Law and its narrative that Myanmar should be united and foreigners could not be trusted and should therefore not be granted citizenship. ${ }^{15}$ The law set out the official ethnic minorities in the country, which were automatically granted citizenship. ${ }^{16}$ However, as the Rohingya were not a recognized ethnic minority of Myanmar, the threshold to attain citizenship under the new law was too high for many Rohingya, thus effectively rendering them stateless. ${ }^{17}$

In subsequent years, the Rohingya faced further discrimination and human rights abuses, justified by Myanmar under the fight against terrorism and security threats. ${ }^{18}$ Several instances, not least the 2012 communal violence, demonstrate how the top-down process of othering and securitization is deeply ingrained in society. ${ }^{19}$ In June 2012, Rakhine witnessed an outbreak of violence including extra-judicial killings, rape, torture, and confiscation of property, after ten Muslim men had been murdered because three Muslim men had raped a Buddhist woman. ${ }^{20}$ The narrative was also spread on Facebook,

10 OHCHR 'Report of the Detailed Findings of the Independent International Fact-Finding Mission on Myanmar' (17 September 2018) UN Doc A/HRC/39/CRP2 (IIFFMM Report) 177-255. In 1989 the military junta changed the country's name from Burma to Myanmar. See Haradhan Kumar Mohajan, 'History of Rakhine State and the Origin of the Rohingya Muslims' (2018) 2 IKAT The Indonesian Journal of Southeast Asian Studies 19, 20.

11 IIFFMM Follow-up Report, 6, 176; UN Special Rapporteur Yanghee Lee, 'Myanmar: "Possible War Crimes and Crimes Against Humanity Ongoing in Rakhine and Chin States"' (29 April 2020) Press Release OHCHR.

12 Afroza Anwary, 'Interethnic Conflict and Genocide in Myanmar' (2020) 24 Homicide Studies 85, 92; The Republic of the Union of Myanmar President Office, 'Executive Summary of Independent Commission of Enquiry - ICOE's Final Report' (21 January 2020) <https://www.presidentoffice.gov.mm/en/?q=briefing-room/news/2020/01/21/id-9838> accessed 22 March 2020 (Summary ICOE Report) 1. Note that Burma was under British rule from 1886 until 1948. See Win (n 9) 253.

13 Win (n 9) 257.

14 Union Citizenship Act 1948 (8 November 1948) Act No LXVI of 1948; Anwary (n 12) 93; Kazi Fahmida Farzana, Memories of Burmese Rohingya Refugees: Contested Identity and Belonging (Palgrave Macmillan 2017) 49-50; Summary ICOE Report (n 12) 1-2; Win (n 9) 257-258.

15 Farzana (n 13) 48-50; Win (n 9) 258.

16 Pyithu Hluttaw Law No 4/1982 (1982 Citizenship Law).

171982 Citizenship Law; Farzana (n 13) 51-53; Mohammad Mahbubul Haque, 'Rohingya Ethnic Muslim Minority and the 1982 Citizenship Law in Burma' (2017) 37 Journal of Muslim Minority Affairs 454, 456-458. The official narrative is that the Rohingya were not interested in applying for citizenship as they identified as ethnic Rohingya which is not mentioned in the law. See Summary ICOE Report (n 12).

18 Nicole Messner and others, 'Qualitative Evidence of Crimes Against Humanity: The August 2017 Attacks on the Rohingya in Northern Rakhine State, Myanmar' (2019) 13(41) Conflict and Health 1, 45; Summary ICOE Report (n 12) 2; Win (n 9) 258-259.

19 Win (n 9) 264, 270-272.

20 ibid 260-261. 
where politicians posted incendiary messages about the Rohingya. ${ }^{21}$ For instance, the Director of President Thein Sein's office announced that they decided to eradicate the Rohingya, further demanding the international community to tolerate any action necessary to achieve this, 'without any outcry for human rights abuses'. ${ }^{22}$ There was another surge of violence in 2016, yet, the most heinous crimes were committed in $2017 .{ }^{23}$ In the early hours of 25 August 2017, the Arakan Rohingya Salvation Army (ARSA), a Rohingya insurgency group, labelled a terrorist group in Myanmar and launched attacks against Myanmar security forces (Tatmadaw). ${ }^{24}$ Myanmar's President immediately authorized 'clearance operations' in Rakhine which mainly targeted the civilians. ${ }^{25}$

\section{B. Ongoing Atrocities ${ }^{26}$}

It is important to know what crimes were committed in order to analyse whether intervention under Pillar III of the R2P is warranted. ${ }^{27} \mathrm{~A}$ valuable source is the Independent International Fact-Finding Mission on Myanmar (IIFFMM) which was established in March 2017 by the HRC. ${ }^{28}$ Myanmar does not accept these findings and therefore established its own fact-finding mission, the Independent Commission of Enquiry (ICOE).$^{29}$ Myanmar claims that the situation in Rakhine is overdramatized, declaring it will take the primary responsibility in solving the issue without external interference. ${ }^{30}$ Myanmar therefore often rebuts the claims made by the IIFFMM, in an effort to shift the blame and white-wash the crimes, thereby trying to demonstrate that any $\mathrm{R} 2 \mathrm{P}$ action is unnecessary.

The IIFFMM Report, supported by other evidence, provides clear evidence of mass killings of civilians in northern Rakhine in 2017. Men, women, and children were shot at, tied to or trapped inside burning buildings, thrown into rivers, had their throats cut with

21 ibid 251-252, 262. The use of Facebook and other media can be compared to the use of media to broadcast hate and incite violence in the Rwandan genocide. This was found to be direct and public incitement to commit genocide and persecution by the International Criminal Tribunal for Rwanda. See Nahimana et al (Media Case) (Appeals Judgment) ICTR-99-52-A (28 November 2007).

22 Win (n 9) 262.

23 Messner (n 18) 2; Summary ICOE Report (n 12) 3.

24 IIFFMM Report (n 10) 177-178; UNSC Presidential Statement 22 (6 November 2017) UN Doc S/PRST/2017/22; Summary ICOE Report (n 12) 3. The ARSA is not the be confused with the Arakan Army (AA), a Buddhist group fighting for more autonomy of Rakhine, which is often in the news.

25 Summary ICOE Report (n 12) 3-4, 10. The term 'clearance operation' is used by officials in Myanmar to refer to military operations targeted at insurgents or terrorists who have intruded or attacked a certain area and to clear it of weapons and terrorists in order to restore peace and stability in the area. In reality these attacks are aimed at removing the Rohingya from Myanmar and therefore mainly target civilians. It has been argued that the nature, scale, and organization of these operations indicate a certain plan or policy, and were not on the spot reactions. See IIFFMM Follow-up Report, 6, 178; Messner (n 18) 7; Summary ICOE Report (n 12) 4.

26 Most of the following crimes were reportedly committed by Myanmar security forces (Tatmadaw), although the ARSA as well as civilians, committed crimes as well. It is important to note that this accounts for the most heinous crimes and the list is not exhaustive. See IIFFMM Report n (11); Summary ICOE Report (n 12).

27 See Chapter III "Discussion of the Status of the Responsibility to Protect".IIFF.

28 IIFFMM Report (n 10).

29 Michael A Becker, 'The Challenges for the ICJ in the Reliance on UN Fact-Finding Reports in the Case Against Myanmar' (EJIL:Talk!, 14 December 2019) <https://www.ejiltalk.org/the-challenges-for-theicj-in-the-reliance-on-un-fact-finding-reports-in-the-case-against-myanmar/> accessed 23 March 2020. The ICOE handed over its final report to the President of Myanmar on $20^{\text {th }}$ January 2020, who then published an Executive Summary thereof. See ICOE, 'Mandate' (ICOE) <https://www.icoemyanmar.org> accessed 22 March 2020.

30 UNGA Verbatim Record (23 December 2017) UN Doc A/72/PV/76, 6. 
machetes, or were stabbed or beaten to death. ${ }^{31}$ Survivors described how they came across numerous mass graves, and that the ground in the villages was sticky because of the blood. $^{32}$

According to the IIFFMM Report, many females who fled to Bangladesh reported that they were victims of rape, gang rape, sexual mutilation, or sexual humiliation. ${ }^{33}$ Women and girls as young as eight-years-old, were separated from men and taken to houses and raped. ${ }^{34}$ Nonetheless, men and boys were also subjected to rape, genital mutilation, and sexualized torture, especially upon arbitrary detention during the clearance operations which took place in August and September 2017. ${ }^{35}$ These victims suffer longlasting mental and physical harm. Some had to be carried to Bangladesh because they were unable to walk, while others died of their wounds. ${ }^{36}$ Between May and June of 2018, there was a spike in numbers of pregnancies in the refugee camps in Bangladesh, many of which were terminated at a late stage. ${ }^{37}$ Survivors recall how Tatmadaw forces entered the villages and successively burned down each house. ${ }^{38}$ Satellite imagery shows burned Rohingya villages, next to intact villages of ethnic Rakhines, demonstrating a deliberate targeting of the minority. ${ }^{39}$

Myanmar claims that the clearance operations which commenced on 25 August 2017 lasted until 5 September 2017. ${ }^{40}$ However, the IIFFMM Follow-up Report confirms that many of the factors that contributed to the 2017 operations are still present. ${ }^{41}$ Rohingya continue to be victims of government attacks formulated to eradicate them from Myanmar. ${ }^{42}$ Hence, the IIFFMM concluded that the situation in Rakhine remained the same, if not deteriorated. ${ }^{43}$ As a result of the 2017 attacks, more than 725,000 Rohingya refugees had arrived in Bangladesh by September 2018. ${ }^{44}$ By March 2020 the 34 refugee camps in Cox's Bazar, Bangladesh are crowded with almost one million Rohingyas. ${ }^{45}$ Furthermore, the IIFFMM calls Myanmar's statements concerning the facilitation of the return of these refugees 'an insincere attempt to appease the government of Bangladesh and the international community'. ${ }^{46}$

31 IIFFMM Report (n 10) 179-220; Messner (n 18) 5-6. cf Summary ICOE Report (n 12) 10. While the ICOE's Executive Summary acknowledges that mass killings occurred, the Presidency attempted to distribute responsibility among all actors equally. It adopts the argument of disproportionate and excessive use of force by individual actors and declares that there have yet to be found any official plans or orders to commit such killings.

32 IIFFMM Report (n 10) 179ff; Messner (n 18) 6-7.

33 IIFFMM Report (n 10) 187-218. cf Summary ICOE Report (n 12) 6. The ICOE's Executive Summary on the other hand states that there were no credible sources proving instances of rape or gang rape, and merely acknowledges that some women had complained about what might amount to sexual violence.

34 Messner (n 18) 7.

35 IIFFMM Report (n 10) 218-220.

36 IIFFMM Report (n 10) 187-218; Messner (n 18) 7.

37 IIFFMM Report (n 10) 217.

38 ibid 221-222; Messner (n 18) 5.

39 IIFFMM Report (n 10) 230-231. cf Summary ICOE Report (n 12) 6. The ICOE Report's declares that arson was not only perpetrated by security forces but also by civilians, including Muslims. Furthermore, it suggests that most houses were burned down after the Rohingya had already exited them.

40 Summary ICOE Report (n 12) 12.

41 IIFFMM Follow-up Report, 6, 176.

42 ibid 6.

43 ibid 6, 176.

44 IIFFMM Report (n 10) 278.

45 OCHA, 'Rohingya Refugee Crisis' (OCHA) <https://www.unocha.org/rohingya-refugee-crisis $>$ accessed 22 March 2020.

46 IIFFMM Follow-up Report, 176. 


\section{The International Community's Response}

Following the 2016 and 2017 attacks, most States issued statements condemning the violence and vocalizing their great concern for the situation ${ }^{47}$ In addition, several States demanded access to northern Rakhine for humanitarian assistance or themselves provided an aid to the Rohingya. ${ }^{48}$ Most importantly however, the European Union (EU), Australia, Canada, and the United States (US) have imposed sanctions on high-ranking military officials in Myanmar. ${ }^{49}$ Moreover, several States have demanded that the United Nations (UN) take action according to its mandate, including a request for a closed SC meeting..$^{50}$ Nonetheless, several States publicly support Myanmar, by asserting their States' close ties to the country, or voting against any resolutions concerning the situation in Myanmar, while others remain silent on the issue. These include most prominently Russia and China, as well as Myanmar's neighbouring countries (apart from Bangladesh). ${ }^{51}$ It follows that

47 This includes, among others, Japan, Mexico and Ukraine; other actors such as the Organization of Islamic Cooperation and several Nobel Peace Laureates have also condemned Myanmar's violence. See Contact Group on Rohingya Muslims of Myanmar, 'Report of the Contact Group on Rohingya Muslims of Myanmar' (25 September 2019) <https://www.oic-oci.org/docdown/?docID=4518\&refID=1255> accessed 4 April 2020; Norio Maruyama, 'The Attacks in Northern Areas of Rakhine State in Myanmar and the Release of the Final Report by the Advisory Commission on Rakhine State' (Press release, Ministry of Foreign Affairs of Japan 29 August 2017); Ministry of Foreign Affairs Mexico, 'Mexico Expresses Concern Over the Situation of the Rohingya Minority in Myanmar' (Press release, Ministry of Foreign Affairs Mexico 11 September 2017); Permanent Mission of Ukraine to the UN in New York, 'Statement by the Delegation of Ukraine at the UNSC Session on the Situation in Myanmar' (Permanent Mission of Ukraine to the UN in New York September 28 2017); Open letter from Muhammar Yunus and others to the President of the Security Council and Member Countries of the Security Council (29 December 2016).

48 Among these are: Austria, Belgium, Canada, Denmark, Finland, France, Greece, Ireland, the Netherlands, Poland, Spain, Sweden, Turkey, and the US as well as Japan. See US Mission Burma, 'Joint Statement on Humanitarian Access to Northern Parts of Rakhine State' (US Mission Burma 9 December 2016); Ministry of Foreign Affairs of Japan, 'Emergency Grant Aid for the People in Myanmar and Bangladesh in Response to the Destabilizing Situation in the Northern Part of Rakhine State, Myanmar' (Press Release, Ministry of Foreign Affairs of Japan 26 September 2017).

49 Council of the EU, 'Myanmar/Burma: Council Adopts Conclusions' (Press Release, Council of the EU 10 December 2018); Department of Foreign Affairs and Trade, 'Sanctions Regimes Myanmar' (Department of Foreign Affairs and Trade Australian Government) <https://www.dfat.gov.au/internationalrelations/security/sanctions/sanctions-regimes/Pages/myanmar> accessed 23 March 2020; Government of Canada, 'Canadian Sanctions Related to Myanmar' (Government of Canada, 14 January 2020) $<$ https://www.international.gc.ca/world-monde/international_relationsrelations_internationales/sanctions/myanmar.aspx?lang=eng> accessed 23 March 2020; John Sifton, 'US Imposes Human Rights Day Sanctions on Myanmar' (HRW, 10 December 2019) $<$ https://www.hrw.org/news/2019/12/10/us-imposes-human-rights-day-sanctions-myanmar> accessed 23 March 2020.

50 These include Bangladesh, Pakistan, Nigeria, the United Kingdom (UK) and Sweden. See Jane Adams , 'Nigeria Condemns Human Rights Abuse in Myanmar' (Press Release, Ministry of Foreign Affairs Nigeria 12 September 2017); Masud Bin Momen, 'Statement by H E Mr Masud Bin Momen Security Council Meeting on the 'Situation in Myanmar" (Permanent Mission of the People's Republic of Bangladesh to the UN 28 September 2017); Boris Johnson, 'Foreign Secretary Calls for an End to Violence in Rakhine' (Press Release, Foreign \& Commonwealth Office and Boris Johnson 2 September 2017); Ministry of Foreign Affairs of Sweden, 'Swedish Statement at the UN Security Council Briefing on the Situation in Myanmar' (Press Release, Ministry of Foreign Affairs 13 February 2018); Prime Minister's Office Islamic Republic of Pakistan, 'Resolution Passed by the Federal Cabinet Against Myanmar on the Rohingya Genocide' (Press Release, Prime Minister's Office Islamic Republic of Pakistan 7 September 2017); Sheikh Hasina,' $73^{\text {rd }}$ Session of the United Nations General Assembly Address by Sheikh Hasina' (Permanent Mission of the People's Republic of Bangladesh to the UN 27 September 2018).

51 This is a non-exhaustive list. See UN Doc A/72/PV/76; UNGA Verbatim Record (27 December 2019) UN Doc A/74/PV/52; Embassy of the People's Republic of China in the United States of America, 
any action within the SC or regional organizations such as the Association of Southeast Asian Nations (ASEAN) is hindered by this. ${ }^{52}$

On 6 November 2017, the SC articulated its grave concern and condemned the violence in Rakhine. ${ }^{53}$ The GA has further adopted a resolution on 23 January 2018 with the aim of aiding the Rohingya refugees and facilitating their safe return to Myanmar where they shall be granted citizenship, and appointing a special envoy to Myanmar. ${ }^{54}$ The HRC adopted resolutions expressing its grave concern over the situation and calling upon Myanmar to take the necessary measures to halt atrocities, and established the IIFFMM and the Independent Investigative Mechanism for Myanmar (IIMM).$^{55}$

On 11 November 2019, The Gambia instituted proceedings against Myanmar before the International Court of Justice (ICJ) regarding a violation of its obligations under the Genocide Convention. ${ }^{56}$ Moreover, on 14 November 2019, Pre-Trial Chamber III of the International Criminal Court (ICC) authorized the Prosecutor to proceed with the investigation of the situation in Bangladesh/Myanmar with regard to the Rohingya. ${ }^{57}$ Yet, both these cases will take several years before a judgment is rendered and thus provide little comfort for the Rohingya currently in crisis.

It is evident that the Rohingya have been victims of discrimination and gross human rights violations for decades. By February 2021, the situation has not significantly improved for the Rohingya. Myanmar is taking very little action to find a viable solution for the issue and is not interested in joining the international community's efforts to put a halt to the atrocities being committed there. The February $1^{\text {st }}, 2021$ military coup d'état and arbitrary arrest and detention of the de facto civilian leader Aung San Suu Kyi further exemplifies the dire human rights situation in the country. Although, multiple States have responded to the Rohingya crisis through condemnations in official statements, economic sanctions, and demands of UN action, none of the responses have effectively improved the

'Wang Yi Holds Talks with U Kyaw Tint Swe, Minister for the Office of the State Counsellor of Myanmar' (Press Release, Embassy of the People's Republic of China in the United States of America 27 August 2019); Ministry of External Affairs Government of India, 'India-Myanmar Joint Statement During State Visit of President to Myanmar (10-14 December 2018)' (Press Release, Ministry of External Affairs Government of India 13 December 2018); Sugam Pokharel and Ben Westcott, 'Philippine Strongman Told Myanmar Leader to Ignore "Noisy" Rights Activists' CNN (Atlanta, 26 January 2018) <https://edition.cnn.com/2018/01/26/asia/duterte-aung-san-suu-kyi-rohingya-intl/index.html> accessed 4 April 2020.

52 See Chapter IV "The Options Before the International Community".

53 UN Doc S/PRST/2017/22.

54 UNGA Res 72/248 (24 December 2017) UN Doc A/RES/72/248.

55 OHCHR 'Situation of Human Rights of Rohingya Muslims and other Minorities in Myanmar' (8 December 2017) UN Doc A/HRC/RES/S-27/1; OHCHR 'Situation of Human Rights of Rohingya Muslims and other Minorities in Myanmar' (3 October 2018) UN Doc A/HRC/RES/39/2; OHCHR 'Situation of Human Rights of Rohingya Muslims and other Minorities in Myanmar' (3 October 2019) UN Doc A/HRC/RES/42/3.

56 Application of the Convention on the Prevention and Punishment of Genocide (The Gambia $v$ Myanmar) (Application Instituting Proceedings and Request for Provisional Measures) <https://www.icjcij.org/files/case-related/178/178-20191111-APP-01-00-EN.pdf > accessed 22 March 2020. In its most recent Order of 23 January 2020 the ICJ ruled that Myanmar must take measures to protect the Rohingya and report on these within four months and then every six months thereafter until the final judgment. How this affects the situation of the Rohingya in Myanmar is yet to be seen. See Application of the Convention on the Prevention and Punishment of Genocide (The Gambia v Myanmar) (Request for Indication of Provisional Measures) (23 January 2020) [76]-[83] <https://www.icj-cij.org/files/case-related/178/17820200123-ORD-01-00-EN.pdf $>$ accessed 4 April 2020.

57 Situation in Bangladesh/Myanmar (Decision on the Authorisation of an Investigation) ICC-01/19 (14 November 2019) <https://www.icc-cpi.int/CourtRecords/CR2019_06955.PDF> accessed 5 April 2020 . 
situation of the Rohingya. It follows that more serious, coordinated measures are called for, for which the R2P serves as the ideal framework.

\section{Discussion of the Status of the Responsibility to Protect A. The Responsibility to Protect Framework and its Application with Regard to Myanmar}

The R2P emerged when the Post-Cold War era witnessed an impasse between the longstanding principle of State sovereignty and the urge to protect populations from atrocity crimes through intervention. ${ }^{58}$ The International Commission on Intervention and State Sovereignty (ICISS) sought to resolve this issue by formulating the 'Responsibility to Protect' doctrine, which was adopted by the World Summit in 2005. ${ }^{59}$ It entailed a threefold commitment proclaimed by each State. Firstly, honouring its own Responsibility to Protect its population from genocide, crimes against humanity, war crimes, and ethnic cleansing. Secondly, assisting other States in doing so and lastly, declaring its willingness to take collective action should a State manifestly fail in protecting its population and more peaceful means prove inadequate. ${ }^{60}$ By identifying 'sovereignty as responsibility', it placed sovereignty at the heart of the debate and allowed for intervention only when a State failed in its own R2P. ${ }^{61}$

Despite its enthusiastic adoption by the GA, the operationalization of the doctrine took some time. It was only in 2009 when United Nations Secretary-General (SG) Ban Kimoon formally laid out the three-Pillar structure. ${ }^{62}$ Pillar I is relatively straight-forward, as States maintain their Responsibility to Protect their population from the four core crimes, which essentially reaffirms principles firmly established in international law. ${ }^{63}$ Pillar II rests on the foundation that a State which is unable to fulfil its responsibility, may obtain support from the international community. ${ }^{64}$ This could be in the form of encouragement, capacitybuilding, or assistance. ${ }^{65}$ However, it is important to recognize that this should be done

58 Nicole Deitelhoff, 'Is the R2P Failing? The Controversies about Norm Justification and Norm Application of the Responsibility to Protect' (2019) 11 Global Responsibility to Protect 149, 152; Yukiko Nishikawa, 'The Reality of Protecting the Rohingya: An Inherent Limitation of the Responsibility to Protect' (2020) 16 Asian Security 90, 98. The narrative was that the world must never again witness another Rwanda, Srebrenica or Cambodia. See UNGA 'Report of the Secretary-General 63/677' (12 January 2009) UN Doc A/63/677 [5]-[6].

59 UNGA Res 60/1 (24 October 2005) UN Doc A/RES/60/1 (WSOD); ICISS, The Responsibility to Protect: Report of the International Commission on Intervention and State Sovereignty (International Development Research Centre 2001). The World Summit was the largest gathering of heads of State, held at the UN Headquarters in New York in September 2005. Over 170 Heads of State and Government unanimously adopted the World Summit Outcome Document (WSOD). A year later the SC affirmed paras 138 and 139 of the WSOD in its Resolution 1674 on the Protection of Civilians in Armed Conflict. See WSOD; UNSC Res 1674 (28 April 2006) UN Doc S/RES/1674.

60 WSOD [138]-[139].

61 ibid; ICISS (n 59) 13; UN, 'Secretary-General Defends, Clarifies 'Responsibility to Protect' at Berlin Event on 'Responsible Sovereignty: International Cooperation for a Changed World" (Press Release, UN 15 July 2008) (SG Berlin Speech).

62 UNGA 'Report of the Secretary-General 63/677' (12 January 2009) UN Doc A/63/677. Although Ban Ki-moon addressed it previously in the SG Berlin Speech in 2008. See SG Berlin Speech (n 61).

63 UN Doc A/63/677 [13]; UNGA Convention on the Prevention and Punishment of the Crime of Genocide (adopted 9 December 1948, opened for signature 11 December 1948, entered into force 12 January 1951) 78 (Genocide Convention); UNGA Rome Statute of the International Criminal Court (adopted 17 July 1998, entered into force 1 July 2002) 2187 UNTS 3 (Rome Statute).

64 UN Doc A/63/677 [28]-[48].

65 UNGA and UNSC 'Report of the Secretary-General A/68/947-S/2014/449' (11 July 2014) UN Doc A/68/947-S/2014/449 [1]. 
preventively rather than reactively. ${ }^{66}$ Lastly, and most controversially, Pillar III sets out the courses of action which the international community may take in order to protect populations from atrocities. These include pacific measures under Chapter VI and VIII, or if these prove inadequate, timely and decisive collective action under Chapter VII of the UN Charter. ${ }^{67}$ This is however to be invoked only if the State in question manifestly fails in its responsibility, and even then, forcible measures should be adopted as a last resort. ${ }^{68}$ It is worth noting that Pillar III entails several non-forcible means, which can be employed without requiring authorization by the SC. ${ }^{69}$ The case of post-election violence in 20072008 in Kenya presents an interesting example, where mediation efforts led to a successful resolution of the conflict. ${ }^{70}$ Authorization for collective action lies with the SC under article 41 or 42 , or by way of authorizing regional arrangements under article $53 .{ }^{71}$ Nevertheless, should the SC fail to exercise its responsibility due to a lack of unanimity among the P5, the GA could act under the Uniting for Peace Resolution, whose outcome would however not be legally binding. ${ }^{72}$ While some claim that further operationalization of the R2P is needed to guarantee its effectiveness, the author is of the opinion that there is a clear set of response that should be promoted rather than criticized. Continuous negotiation of the precise framework will not improve its effectiveness, as each situation is assessed individually and the responses are not novel, but are already encompassed in the wellestablished UN-framework.

As proved by the institutionalized discrimination towards the Rohingya, Myanmar is not seeking to alleviate their suffering. It therefore becomes apparent that, as the State is the perpetrator of the atrocity crimes which also refuses to consent to international assistance, a Pillar III solution is the only option. ${ }^{73}$ Moreover, if a State is the perpetrator and is considered to be 'manifestly failing' in its responsibility, it is not necessary to assess a Pillar II response first, rather, the focus should be on a timely and decisive reaction. ${ }^{74}$

The scholar Lindsey Kingston advanced an interesting argument that the R2P should not merely be equated with military intervention, but should focus on non-violent prevention mechanisms to stop mass atrocities in progress. ${ }^{75}$ While she is right in asserting that forcible intervention is not the only tool in the box, her line of reasoning neglects the fact that where mass atrocities are ongoing, prevention mechanisms are inadequate. ${ }^{76} \mathrm{In}$ such cases, action under Pillar III albeit not forcible, might serve as a better response. Alex

66 SG Berlin Speech (n 61).

67 UN Doc A/63/677 [49].

68 ibid [49]-[50].

69 ibid [51].

70 SG Berlin Speech (n 61). Many claim it was dubbed R2P only after its successful completion in an effort to influence the R2P debate. See Julian Junk, 'Bringing the Non-Coercive Dimensions of R2P to the Fore: The Case of Kenya' (2016) 30 Global Society 54, 58, 61.

71 UN Doc A/63/677 [56].

72 UNGA Res 377 (V) (3 November 1950) UN Doc A/Res/377(V) (Uniting for Peace); UN Doc A/63/677 [63].

73 Adrian Gallagher, 'The Promise of Pillar II: Analysing International Assistance under the Responsibility to Protect' (2015) 91 International Affairs 1259, 1263.

74 UN Doc A/63/677 [29]; Gallagher, 'The Promise of Pillar II' (n 73) 1267. The academic Adrian Gallagher suggests further criteria to assess a 'manifest failing'. These include government intentions, weapons used, death toll, number of people displaced, and the intentional targeting of civilians especially women, children and the elderly, yet in his argument he makes clear that each situation is best assessed on a case-by-case basis. See Adrian Gallagher, 'What Constitutes a 'Manifest Failing'? Ambiguous and Inconsistent Terminology and the Responsibility to Protect' (2014) 28 International Relations 428, 437439.

75 Lindsey N Kingston, 'Protecting the World's Most Persecuted: The Responsibility to Protect and Burma's Rohingya Minority' (2015) 19 The International Journal of Human Rights 1163, 1172.

76 See supra, $\mathrm{n} 74$. 
Bellamy correctly reasoned that 'there would be obvious moral objections to a concept that demanded that the world's first response to the Rwandan genocide should have been to "assist" the regime that was largely responsible'. ${ }^{77}$

\section{B. Previous Efforts with Regard to the Responsibility to Protect and its Impact}

While Pillar I references in UN documents, emphasizing a State's primary Responsibility to Protect its population, are rather frequent, Pillar II cases are less common. ${ }^{78}$ Some Pillar II cases, where assistance was provided to a State struggling to meet its own R2P will briefly be explained below. ${ }^{79}$ The Central African Republic and South Sudan encompassed similar situations. In both cases, the SC had already been assisting the government when the situations deteriorated and the SC expanded the mandate of its mission by shifting from capacity building to protecting civilians. ${ }^{80}$ Another example is Resolution 2100, where the $\mathrm{SC}$ authorized requested assistance in Mali, which was provided by several actors, not least the African Union and the Economic Community of West African States. ${ }^{81}$ However, in Côte d'Ivoire, Pillar II was taken a step further. While the legitimate Head of State Mr. Ouattara requested assistance from the international community, critics claim the mandate was exceeded through the use of coercion aimed at disposing of President Gbagbo. ${ }^{82}$

Although non-forcible measures have been applied under Pillar III, for example in Kenya in 2008, the most influential case has been the military intervention in Libya. While SC Resolution 1973 enforced a 'no-fly zone' and a 'no-walk zone', hence preventing regime change, many argue that the intervening North Atlantic Treaty Organization (NATO) forces did just that. ${ }^{83}$ The NATO countries later argued that a leader who himself is perpetrating atrocities against civilians cannot stay in power. ${ }^{84}$ Nevertheless, regime change was not envisaged in SC Resolution 1973 authorizing intervention and even feared by some and therefore led to global criticism among academics and States alike. ${ }^{85}$ Concerns

77 Alex J Bellamy, 'Making RtoP a Living Reality: Reflections on the 2012 General Assembly Dialogue on Timely and Decisive Response' (2013) 5 Global Responsibility to Protect 109, 113.

78 See supra, n 64. References to Pillar I reiterate a State's own responsibility and do not call for any action, except from the State in question. Such references are utilized to assert a State's sovereignty while reminding it of its obligations. As such, they present an easy way out, as the relevant UN body can demonstrate the importance of human rights and the R2P, while in essence, no substantive action from its member States is required. The SC has issued a presidential statement asserting Myanmar's primary Responsibility to Protect its population in 2017. See infra, n 122.

79 See supra, n 65.

80 UNSC Res 2127 (5 December 2013) UN Doc S/RES/2127; UNSC Res 2149 (10 April 2014) UN Doc S/RES/2149; UNSC Res 2155 (27 May 2014) UN Doc S/RES/2155; Spencer Zifcak, 'What Happened to the International Community? R2P and the Conflict in South Sudan and the Central African Republic' (2015) 16 Melbourne Journal of International Law 52, 59-60, 63-66, 81.

81 UNSC Res 2100 (25 April 2013) UN Doc S/RES/2100.

82 UNSC Res 1975 (30 March 2011) UN Doc S/RES/1975; Gallagher, 'The Promise of Pillar II' (n 73) 1266.

83 UNSC Res 1973 (17 March 2011) UN Doc S/RES/1973; Nesam McMillan and David Mickler, 'From Sudan to Syria: Locating 'Regime Change' in R2P and the ICC' (2013) 5 Global Responsibility to Protect 283, 304-306; Paul Tang Abomo, R2P and the US Intervention in Libya (Palgrave Macmillan 2019) 242246; Thomas G Weiss, 'Libya, R2P, and the United Nations' in Dag Henriksen and Ann Karin Larssen (eds), Political Rationale and International Consequences of the War in Libya (OUP 2016) 8-9. The vote was ten in favor and five (China, Russia, Brazil, Germany and India) abstaining. See UNSC Verbatim Record (17 March 2011) UN Doc S/PV/6498.

84 McMillan and Mickler (n 83) 306; Weiss (n 83) 9.

85 UN Doc S/RES/1973; McMillan and Mickler (n 83) 306-307. Criticism for regime change was communicated among others by China, Russia, India, South Africa and Pakistan. See UNSC Verbatim 
that Libya would establish a precedent for regime change was emphasized in the Syrian crisis. ${ }^{86}$

Syria is in danger of setting a precedent of inaction, caused by the Chinese and Russian veto. ${ }^{87} \quad$ It further demonstrates that those capable are willing to condemn, but not to act, proving that passivity remains an option. ${ }^{88}$ The Sino-Russian bloc justified the use of their veto by asserting concern about the abuse for regime change. ${ }^{89}$ Yet, in a subsequent draft resolution that explicitly precluded military intervention they continued to use their veto, thereby substantially weakening their case. ${ }^{90}$ Unfortunately, this was not the only time the SC stood by and did nothing. In 2008 and 2009, Sri Lanka witnessed war crimes resulting in about 40,000 casualties, while the international community failed to address the issue effectively. ${ }^{91}$ Additional examples include a stalled response in Yemen, North Korea and of course Myanmar. ${ }^{92}$

The academic Jess Gifkins argues that R2P language has been more frequently invoked in the SC, especially since Libya.$^{93}$ Nevertheless, she stresses that while there is less objection towards the use of R2P language, Pillar III invocations remain rare. ${ }^{94}$ However, scholar Aidan Hehir rightly points out that increasing R2P references should not necessarily be interpreted as progress. ${ }^{95}$ In fact, the contrary is the case. He claims that the SC has used R2P language in a way to legitimize their inaction by emphasizing the host State's primary responsibility, thereby shifting liability. ${ }^{96}$ Nonetheless, this behaviour can mostly be attached to Sino-Russian views of the doctrine, as they see the R2P only in terms of Pillar I and II and have shown a pattern of vetoing concrete R2P responses. ${ }^{97}$ The SC thus comes to a typical deadlock of the West against the rest.

Record (4 October 2011) UN Doc S/PV/6627; UNSC Verbatim Record (4 February 2012) UN Doc $\mathrm{S} / \mathrm{PV} / 6711$.

86 Zheng Chen and Hang Yin, 'China and Russia in R2P Debates at the UN Security Council' (2020) International Affairs $4 \quad<$ https://academic.oup.com/ia/articleabstract/doi/10.1093/ia/iiz229/5712435?redirectedFrom=fulltext> accessed 24 March 2020; McMillan and Mickler (n 83) 307; Tang Abomo (n 83) 247; Zifcak (n 80) 81.

87 Chen and Yin (n 86) 4-5; Tor Dahl-Eriksen, 'R2P and the UN Security Council: An "Unreliable Alliance"' (2019) 36 International Journal on World Peace 33, 42-43.

88 Jean-Marc Coicaud, 'International Law, the Responsibility to Protect and International Crises' in Ramesh Thakur and William Maley (eds), Theorising the Responsibility to Protect (CUP 2015) 169-171, 177; Global Centre for the Responsibility to Protect, 'Syria' (Global R2P, 15 March 2020) $<$ https://www.globalr2p.org/countries/syria/> accessed 26 March 2020; Weiss (n 83) 9-10.

89 UN Doc S/PV/6627; McMillan and Mickler (n 83) 307-308.

90 The second time they argued the respect for the principle of State sovereignty, but both times they failed to mention their national interest in Syria. See UN Doc S/PV/6711; McMillan and Mickler (n 83) 308.

91 Dahl-Eriksen (n 87) 44; Weiss (n 83) 14.

92 Jared Genser, 'The UN Security Council's Implementation of the Responsibility to Protect: A Review of Past Interventions and Recommendations for Improvement' (Policy Brief, Global Centre for the Responsibility to Protect 2018) <http://responsibilitytoprotect.org/files/un-security-councilapplication-of-r2p-jared-genser.pdf $>$ accessed 26 March 2020, 4-5.

93 Jess Gifkins, 'R2P in the UN Security Council: Darfur, Libya and Beyond' (2016) 51 Cooperation and Conflict 148, 157-161.

94 ibid 157, 160.

95 Aidan Hehir, Hollow Norms and the Responsibility to Protect (Palgrave Macmillan 2019) 142.

96 ibid.

97 Chen and Yin (n 86) 4-5; Hehir (n 95) 143-144. 


\section{The Legal Basis of the Responsibility to Protect}

Since its emergence on the international agenda in 2005, the R2P has undergone a process of contestation, which greatly shaped its content. ${ }^{98}$ Most importantly, Russia and China demonstrated time and again that they will veto any resolution in the SC which could lead to regime change and that this must not be encompassed in the emerging norm. ${ }^{99}$

Another important aspect is the perception of the doctrine as a right, yet not an obligation to intervene. ${ }^{100}$ The argument that the doctrine contains such a duty has been rejected by several States, both weak and powerful. ${ }^{101}$ One interesting example is US representative to the UN John Bolton's letter in which he explicitly crossed out the word obligation to replace it with responsibility in the World Summit Outcome Document (WSOD) draft, and argued that it is not of a legal character and that the decision to intervene should remain with the SC. ${ }^{102}$ Scholar Anne Orford likewise argues that the language in R2P documents is of a character to confer authority and allocate powers rather than impose duties. ${ }^{103}$ Thus, it has been argued by several scholars that as the WSOD did not seek to alter the rules on jus ad bellum, support for it was easier to obtain. ${ }^{104}$

Additionally, States have taken an approach that differentiates the responsibility of States to protect their own population and that of the international community to intervene in case of a manifest failure. The latter does not receive widespread support and is invoked far less frequently. ${ }^{105}$ A State's Responsibility to Protect its own population is long entrenched in various treaties, whose object was not only to hold States accountable once atrocities have occurred but also to prevent them from happening in the first place. ${ }^{106}$ Yet, as Pillar III constitutes the means by which the R2P is enforced, without States' willingness to invoke it, the R2P is significantly undermined. ${ }^{107}$

State practice coupled with opinio juris indicates whether a norm has attained the status of customary international law (CIL) ${ }^{108}$ More precisely, State practice needs to be widespread and representative, with specific attention brought to States especially affected, such as the P5 in this case. ${ }^{109}$ States must furthermore act out of a feeling of legal obligation,

98 Hehir (n 95) 109. The R2P as it stands today is different from what the ICISS imagined it to be. cf ICISS (n 59).

99 UN Doc S/PV/6627; Chen and Yin (n 86) 4-7, 12; Deitelhoff (n 58) 171.

100 Alex J Bellamy and Edward C Luck, The Responsibility to Protect: From Promise to Practice (Polity Press 2018) 56-57.

101 Andreas S Kolb, The UN Security Council Member's Responsibility to Protect (Springer 2018) 520; Anne Orford, International Authority and the Responsibility to Protect (CUP 2011) 23-24; Thomas Ramopoulos, 'International Law and the Application of the Third Pillar Approach' in Daniel Fiott and Joachim Koops (eds), The Responsibility to Protect and the Third Pillar (Palgrave Macmillan 2015) 12-13.

102 Letter from John Bolton Representative of the United States to the UN to UN Member States (30 August 2005).

103 Orford (n 101) 25-26. See also Kolb (n 101) 522.

104 Charter of the United Nations (adopted 26 June 1945, entered into force 24 October 1945) 33 UNTS 993 (UN Charter) art 2(4), arts 39-42; Alex J Bellamy and Ruben Reike, 'The Responsibility to Protect and International Law' (2010) 2 Global Responsibility to Protect 267, 273; Dahl-Eriksen (n 87) 42; Hehir (n 95) 108.

105 Chen and Yin (n 86) 3; Deitelhoff (n 58) 171; Kolb (n 101) 522.

106 See eg Genocide Convention; Rome Statute arts 6-8; Case Concerning Application of the Convention on the Prevention and Punishment of the Crime of Genocide (Bosnia and Herzegovina $v$ Serbia and Montenegro) (Judgment) [2007] ICJ Rep 43.

107 Hehir (n 95) 108-109.

108 Statute of the International Court of Justice (adopted 26 June 1945, entered into force 24 October 1945) 33 UNTS 993 (ICJ Statute) art 38; North Sea Continental Shelf Cases (Federal Republic of Germany v Denmark; Federal Republic of Germany v Netherlands) [1969] ICJ Rep 3 [74], [77].

109 North Sea Continental Shelf Cases (n 108) [74]; Ramopolous (n 101) 11. 
evidenced for example through GA resolutions. ${ }^{110}$ Nevertheless, if a State persistently objects to the legality of a rule, it does not become binding on that State. ${ }^{111}$ Consequently, if several States do so, they can stop the doctrine from becoming CIL at all. ${ }^{12}$

With regard to the R2P, State practice is limited and non-uniform. While the SC took action in some instances, it also abstained from acting in several others. ${ }^{113}$ Although $\mathrm{SC}$ resolutions specifically referencing the R2P have increased, actual practice with regard to Pillar II or III has not. ${ }^{114}$ Moreover, the international community is giving little evidence that it considers the R2P legally binding. ${ }^{115}$ For instance, Resolution 1674 on the Protection of Civilians in Armed Conflict was preceded by debates regarding the status of R2P, which arose again in Resolution 1706 which called upon Darfur to allow military assistance. ${ }^{116}$ The negotiations centred around Russian and Chinese claims that they had only agreed to further discuss the R2P, not to implement it. ${ }^{117}$ While Libya shaped concern about the abuse of R2P, it also led States to assert the non-binding nature and flawed implementation of the doctrine. ${ }^{118}$ Nevertheless, the R2P is frequently mentioned in GA, SC, and HRC resolutions. ${ }^{119}$

It follows that as the R2P doctrine's actionable part is still widely contested and State practice has neither been widespread nor representative, it should be regarded as

110 Case Concerning the Military and Paramilitary Activities in and against Nicaragua (Nicaragua $v$ United States of America) [1986] ICJ Rep 14 [188]; North Sea Continental Shelf Cases (n 108) [77].

111 Fisheries (United Kingdom v Norway) (Judgment) [1951] ICJ Rep 116, 131.

112 ibid.

113 See Chapter III-B "Previous Efforts with Regard to the Responsibility to Protect and Their Impact".

114 Hehir (n 95) 205; Kolb (n 101) 519-522; Ramopoulos (n 101) 12; Zifcak (n 80) 81.

115 Chen and Yin (n 86) 4-5; Kolb (n 101) 519.

116 UN Doc S/RES/1674; UNSC Res 1706 (31 August 2006) UN Doc S/RES/1706; Deitelhoff (n 58) 154155, 165-166. See supra, n 59.

117 ibid.

118 Chen and Yin (n 86 ) 4-5; David Pressman US Representative to the UN, 'Statement at the 2016 United Nations General Assembly Informal Interactive Dialogue on the Responsibility to Protect' (6 September 2016); Deitelhoff (n 58) 166-167; Matthew Rycroft UK Representative to the UN, 'Statement at the 2016 United Nations General Assembly Informal Interactive Dialogue on the Responsibility to Protect (6 September 2016); Representative of China to the UN, 'Statement at the 2016 United Nations General Assembly Thematic Panel Discussion 'From Commitment to Implementation: Ten years of Responsibility to Protect" (Global R2P 26 February 2016); Representative of France to the UN, 'Statement at the 2016 United Nations General Assembly Informal Interactive Dialogue on the Responsibility to Protect' (Global R2P 6 September 2016); Representative of the Russian Federation to the UN, 'Statement at the 2016 United Nations General Assembly Informal Interactive Dialogue on the Responsibility to Protect' (Global R2P 6 September 2016); Representative of the Russian Federation to the UN, 'Statement at the 2016 United Nations General Assembly Thematic Panel Discussion 'From Commitment to Implementation: Ten years of Responsibility to Protect" (Global R2P 26 February 2016).

119 Global Centre for the Responsibility to Protect, 'UN Security Council Resolutions and Presidential Statements Referencing R2P' (Global R2P, 17 January 2020) < https://www.globalr2p.org/resources/unsecurity-council-resolutions-and-presidential-statements-referencing-r2p/> accessed 29 March 2020; Global Centre for the Responsibility to Protect, 'United Nations General Assembly Resolutions Referencing R2P' (Global R2P, 28 October 2019) <https://www.globalr2p.org/resources/un-generalassembly-resolutions-referencing-r2p-2/> accessed 29 March 2020; Global Centre for the Responsibility to Protect, 'UN Human Rights Council Resolutions Referencing R2P' (Global R2P, 18 October 2019) $<$ https://www.globalr2p.org/resources/un-human-rights-council-resolutions-referencing-r2p/> accessed 29 March 2020. Additionally, the SG releases an annual report on the R2P, which is then followed by either a formal debate or an informal interactive dialogue held by the GA where affirmative statements, though mainly with regard to Pillar I, are plenty. See Peter Thomson, 'President's Summary of the Informal Interactive Dialogue of the 71st Session of the General Assembly on the Responsibility to Protect: Implementing the Responsibility to Protect: Accountability for Prevention' (6 September 2017). 
being of a political and moral rather than legal nature. ${ }^{120}$ Yet, the doctrine is valuable despite its soft-law status and should not be disregarded in future instances of mass atrocities.

\section{The Options Before the International Community A. Security Council Action}

Following the attacks starting on 25 August 2017, the SC has been briefed by various actors on numerous occasions, yet failed to adopt any conclusive measures to react to the crisis. ${ }^{121}$ It issued only one official document, a presidential statement stressing Myanmar's primary Responsibility to Protect its population, condemning the violence and welcoming Myanmar's efforts to address the root causes of the crisis, including the establishment of the Advisory Commission on Rakhine State. ${ }^{122}$

It is evident that any resolution within the SC needs to be supported by all P5. In that regard, Russian and Chinese arguments in similar circumstances have focused on the principles of State sovereignty and non-intervention, and the fear of abuse (i.e. regime change) of the R2P doctrine. In the context of Myanmar, Russia and China stress the need for a political dialogue rather than concrete action, as in their view that would worsen the state of affairs. ${ }^{123}$

120 Deitelhoff (n 58) 164; Kolb (n 101) 522-523; Ramopoulos (n 101) 15-16.

${ }^{121}$ Mohammad Tanzimuddin Khan and Saima Ahmed, 'Dealing with the Rohingya Crisis: The Relevance of the General Assembly and R2P' [2019] Asian Journal of Comparative Politics 1, 4; Simon Adams, 'The Responsibility to Protect and the Fate of the Rohingya' (2019) 11 Global Responsibility to Protect 435, 443-444; Department of Political Affairs - Security Council Affairs Division, 'Repertoire of Practice of the Security Council: Part I' (20th supplement, 2016-2017) $<$ https://www.un.org/en/sc/repertoire/2016-2017/Part_I/2016-2017_Part_I.pdf\#page=121> accessed 13 May 2020; Department of Political Affairs - Security Council Affairs Division, 'Repertoire of Practice of the Security Council: Part I' (21st supplement, 2018) $<$ https://www.un.org/securitycouncil/sites/www.un.org.securitycouncil/files/scpcrb.repertoire.part_i ._21st_supplement_2018_for_webposting_0.pdf> accessed 13 May 2020; United Nations Digital Library, 'Security Council - Myanmar' (United Nations) $<\mathrm{https}: / /$ digitallibrary.un.org/search? $\mathrm{ln}=$ en\&cc $=$ Security+Council\&p=Myanmar\&f=\&action_search= Search \&rm $=\& \ln =$ en $\& \mathrm{sf}=\& \mathrm{so}=\mathrm{d} \& \mathrm{rg}=50 \& \mathrm{c}=$ Security + Council $\& \mathrm{c}=\& \mathrm{of}=\mathrm{hb} \& \mathrm{fti}=0 \& \mathrm{fct} \_1=$ Meeting $+\mathrm{R}$ ecords\&fct_2 $=$ Security+Council\&fct_3 $=2020 \& \mathrm{fct} \_3=2019 \& \mathrm{fct} \_3=2018 \& \mathrm{fct} \_3=2017 \& \mathrm{fti}=0 \& \mathrm{fct}$ $\_1=$ Meeting + Records\&fct_2 $=$ Security + Council\&fct_3 $=2020 \& \mathrm{fct} \_3=2019 \& \mathrm{fct} \_3=2018 \& \mathrm{fct} \_3=2$ $017>$ accessed 13 May 2020.

${ }_{122}$ UNSC Presidential Statement 22 (6 November 2017) UN Doc S/PRST/2017/22. The Advisory Commission, chaired by former SG Kofi Annan, was set up in autumn 2016 and presented its findings to the authorities of Myanmar on 23 August 2017, two days before the attacks happened. It had suggested interim recommendations in March 2017, for which Myanmar took steps to implement. However, this leaves questions regarding the sincerity of the efforts of Myanmar, while demonstrating the complexity and deep roots of the problem. See Advisory Commission on Rakhine State, 'Towards a Peaceful, Fair and Prosperous Future for the People of Rakhine: Final Report of the Advisory Commission on Rakhine State' August 2017) <http://www.rakhinecommission.org/app/uploads/2017/08/FinalReport_Eng.pdf> accessed 10 April 2020; Kofi Annan, 'Remarks by Kofi Annan, Chairman of the Advisory Commission on Rakhine State' (Advisory Commission on Rakhine State 24 August 2017). The SC held a closed meeting on Myanmar on the 4th of February 2020, following the notice of the provisional measures ordered by the ICJ to the SC subsequent to article 41(2) of the UN Charter. The SC failed to adopt any resolution or presidential statement on this meeting. The next closed meeting concerning Myanmar was set for the 14th of May 2020, in which the SC failed again in adopting any official document or press statement. See United Nations Security $\quad$ Council, 'Meetings' 16 (United
$<$ https://www.un.org/securitycouncil/content/meetings> accessed 16 May 2020.

Nations)

${ }^{123}$ These arguments are in line with the demands of Myanmar. See UNSC Verbatim Record (28 September 2017) UN Doc S/PV/8060; UNSC Verbatim Record (13 February 2018) UN Doc S/PV/8179. 
Political reality dictates that States guard their national interests and in this instance, the national interests of Russia and China do not appear to coincide with any concrete measures, therefore, the R2P remains on the side-lines. ${ }^{124}$ The domestic considerations that dictate the response to the Rohingya crisis include strong economic and military ties to Myanmar, geopolitical considerations, Myanmar's strategic importance with regard to security, transit rights, natural resources and energy security, and the internal problems with their own respective Muslim population. ${ }^{125}$ While these factors appear to be the basis for strong opposition of the Sino-Russian bloc, there is little political will to overcome this obstruction. ${ }^{126}$ Neither the US nor Britain sees the Rohingya crisis as a priority because they have too little economic and strategic interests in Myanmar. ${ }^{127}$

Posterior to the inaction in Syria, a French-Mexican initiative proposed a Code of Conduct calling for a suspension of the veto of the P5 in cases of mass atrocities. ${ }^{128}$ Notwithstanding the effects such political pressure could have had, one scholar Bolarinwa Adediran, points out that Russia, China, and the US are highly unlikely to restrain themselves on the use of the veto, which is essential to the relations among the P5, thereby emphasizing the political reality within the SC. ${ }^{129}$ Nevertheless, if observed by the P5, this would be a break-through for atrocity responses and should therefore not be denied its potential.

As demonstrated in the previous section, the R2P currently holds a soft law status and is regarded as a (moral) right, rather than a duty, to intervene. ${ }^{130}$ If States decide to

124 Tor Dahl-Eriksen, 'R2P and the UN Security Council: An "Unreliable Alliance"' (2019) 36 International Journal on World Peace 33, 42; Khan and Ahmed (n 121) 3-4; Imran Syed, 'To Intervene or Not to Intervene: Ethics of Humanitarian Intervention in Myanmar' (2019) 14 Islamabad Policy Research Institute Journal 111, 118.

${ }^{125}$ Zheng Chen and Hang Yin, 'China and Russia in R2P Debates at the UN Security Council' (2020) International Affairs <https://academic.oup.com/ia/articleabstract/doi/10.1093/ia/iiz229/5712435?redirectedFrom=fulltext> accessed 24 March 2020, 18-19; Khan and Ahmed (n 121) 12-13; Mohammad Zahidul Islam Khan, 'Pathways to Justice for "Atrocity Crimes" in Myanmar: Is There Political Will?' (2019) 11 Global Responsibility to Protect 3, 24-26; Syed (n 124) 122-124.

${ }^{126}$ A possible solution to overcome the obstruction will be discussed in the next section. See infra, The General Assembly.

127 Khan and Ahmed (n 121) 5; Syed (n 124) 123.

${ }^{128}$ Political Statement on the Suspension of the Veto in Cases of Mass Atrocities (Presented by France and Mexico at the $70^{\text {th }}$ UNGA meeting, 2015) $<$ https://onu.delegfrance.org/IMG/pdf/2015_08_07_veto_political_declaration_en.pdf $>$ accessed 10 April 2020. This political statement is supported by 104 States and exists alongside a similar proposal by the Accountability, Coherence and Transparency (ACT) Group calling for all SC members not to vote against any credible draft resolution intended to put a halt to atrocity crimes, which is supported by 117 member States and 2 observers, including France and the UK. Moreover, former Special Adviser to the SG on the R2P Ivan Simonovic fully endorsed both initiatives. See Ivan Simonovic, 'The Responsibility to Protect' (UN Chronicle, 26 January 2017) <https://www.un.org/en/chronicle/article/responsibilityprotect> accessed 10 April 2020; Letter from the Permanent Representative of Liechtenstein to the UN addressed to the SG (14 December 2015); Permanent Mission of France to the UN in New York, 'The UN Reform' (Permanent Mission of France to the UN in New York, 13 December 2019) $<$ https://onu.delegfrance.org/The-UN-Reform> accessed 10 April 2020; Permanent Mission of the Principality of Liechtenstein to the UN New York, 'List of Supporters of the Code of Conduct Regarding Security Council Action against Genocide, Crimes against Humanity or War Crimes, as Elaborated by ACT' (1 January 2019) <https://www.globalr2p.org/resources/list-of-signatories-to-the-act-code-ofconduct/> accessed 10 April 2020.

${ }^{129}$ Bolarinwa Adediran, 'Implementing R2P: Towards a Regional Solution?' (2017) 9 Global Responsibility to Protect $459,460$.

${ }^{130}$ See supra, Chapter III-C "The Legal Basis of the Responsibility to Protect". 
intervene, they can legitimately do so under the UN Charter through the SC framework, but there is no obligation to do so and as the Code of Conduct initiative demonstrates, there are few effective tools to stop the P5 from blocking action. There is no legal obligation to apply the R2P, and accordingly, there are no consequences should States fail to do so. When coupled with the geopolitical considerations at the time and the lack of incentive to apply the R2P this brings about, inaction like in the situation of Myanmar becomes possible.

\section{B. The General Assembly}

When a State refuses to accept measures under Pillar II, it manifestly fails to protect its population from atrocity crimes, and less coercive measures prove inadequate, GA action is foreseen whenever the SC fails to adopt collective measures due to a lack of unanimity among the P5. ${ }^{131}$ While some claim that this lack of unanimity in the SC must be evidenced by a veto, the author believes that it can also include lack of unanimity which already hinders any negotiation of substantive action. When interpreting the Uniting for Peace Resolution in accordance with the plain meaning rule, it does not demand a prior veto. Therefore, the author believes the situation of Myanmar, where the Sino-Russian bloc is unwilling to consider substantive action, suffices to evidence a lack of unanimity. In such a situation, the SC on the vote of any 7 members, or a majority of the members of the GA, can request either a special session under article 20 or an emergency session, under the Uniting for Peace procedure. ${ }^{132}$ Upon failure of the SC to exercise its primary responsibility for the maintenance of international peace resulting from a lack of unanimity, the GA may recommend collective measures it deems necessary to maintain or restore international peace and security. ${ }^{133}$ In exercising these powers the GA is restricted in that it must refer to the SC any question in which coercive or enforcement action is necessary. ${ }^{134}$ While article 12 of the UN Charter provides that the GA may not exercise its functions with regard to a matter with which the SC is exercising its function at that moment, unless it so requests, the ICJ noted that the SC and GA often deal in parallel with the same matter regarding the maintenance of international peace and security. ${ }^{135}$ It is however important to note that the GA recommendations are non-binding. ${ }^{136}$ Nevertheless, such recommendations have considerable moral force, especially when the matter has been referred to the GA by the SC. ${ }^{137}$

At the time of writing, due to the lack of political will and the absence of unanimity among the P5, the SC failed to adopt any resolution concerning the situation in Rakhine.

131 UNGA 'Report of the Secretary-General 63/677' (12 January 2009) UN Doc A/63/677 [56], [63].

132 Charter of the United Nations (adopted 26 June 1945, entered into force 24 October 1945) 33 UNTS 993 (UN Charter) art 20; UNGA Res 377 (V) (3 November 1950) UN Doc A/Res/377(V) (Uniting for Peace) [1]; Khan and Ahmed (n 121) 17.

133 Such recommendations may include collective non-coercive measures or, in case of a breach of the peace or act of aggression, the use of armed force. Moreover, while the SC has the primary responsibility for the maintenance of international peace and security, the GA has a residual responsibility, which is equally authoritative. See Uniting for Peace [1].

134 UN Charter art 11(2); Certain Expenses of the United Nations (Advisory Opinion) [1962] ICJ Rep 151, 164165; Rebecca Barber, 'Accountability for Crimes against the Rohingya: Possibilities for the General Assembly Where the Security Council Fails' (2019) 17 Journal of International Criminal Justice 557, 563564.

135 UN Charter art 12. Thus, although the SC is seized of the matter and is briefed on the situation on a regular basis, the GA may exercise its residual responsibility for the maintenance of international peace and security in parallel. See Legal Consequences of the Construction of a Wall in the Occupied Palestinian Territory (Advisory Opinion) [2004] 136 [27].

136 UN Doc A/63/677 [63].

137 Barber (n 134) 567, 574-575. 
It has been demonstrated by various actors that the crisis in Myanmar is witness to gross human rights abuses and possible international crimes, which present a threat to the peace. ${ }^{138}$ Hence, there is nothing preventing the GA from issuing collective, non-forcible recommendations under a Uniting for Peace procedure, thereby ensuring the international community lives up to its R2P. ${ }^{139}$

\section{International Courts}

Where the international community fails to adopt measures to put a halt to atrocity crimes, international courts can play a substantial role in ensuring that international law is upheld. ${ }^{140}$ Despite it taking several years for an international court to render a judgment, therefore making its usefulness as a primary response to atrocities limited, it may still serve justice. This is especially true in the case of The Gambia v Myanmar where the ICJ ordered Myanmar to adopt provisional measures to protect the Rohingya, thereby offering them reassurance that they are not forgotten. ${ }^{141}$ Nonetheless, a case before the ICC can be just as viable, especially as it serves the primary purposes of punishment in international criminal law; retribution and deterrence. ${ }^{142}$ Furthermore, the two cases complement each other as the ICJ ensures State responsibility, while the ICC holds individual perpetrators to account, and focuses on a more victim-centred approach. ${ }^{143}$

The ICC is currently investigating crimes committed against the Rohingya on the territory of Bangladesh. ${ }^{144}$ Yet, considering the limited amount of crimes over which the ICC has jurisdiction in the situation of Bangladesh/Myanmar, it is worth assessing whether the SC could refer the situation to the ICC, thereby circumventing the fact that Myanmar is not a State party to the Rome Statute (RS). At face value, the answer is in the affirmative. The SC may, acting under Chapter VII, refer any situation to the ICC Prosecutor in which a crime under the RS appears to have been committed. ${ }^{145}$ However, upon taking a closer look, it becomes evident that a SC referral of a situation to the ICC

138 ibid 571-572.

139 Such measures may include targeted sanctions, such as on travel, financial transfers, luxury goods and arms, or alternatively it could establish an ad hoc tribunal. However, in light if the current case of The Gambia v Myanmar before the ICJ and the situation of Bangladesh/Myanmar at the ICC, it is questionable what new prospects such a tribunal would bring. See Un Doc A/63/677 [56]-[57]; Barber (n 134) 580583.

140 Adams (n 121) 447.

141 Application of the Convention on the Prevention and Punishment of Genocide (The Gambia v Myanmar) (Request for Indication of Provisional Measures) (23 January 2020) <https://www.icj-cij.org/files/caserelated/178/178-20200123-ORD-01-00-EN.pdf> accessed 11 April 2020 [79]-[82]; Priya Pillai, 'ICJ Order on Provisional Measures: The Gambia v Myanmar' (Opinio Juris, 24 January 2020) <http://opiniojuris.org/2020/01/24/icj-order-on-provisional-measures-the-gambia-v-myanmar/> accessed 11 April 2020. .

142 Robert Cryer, Darryl Robinson and Sergey Vasiliev, An Introduction to International Criminal Law and Procedure (4th edn, CUP 2019) 468.

143 Konstantinia Stavrou, 'And the Victim's Voices?' (Völkerrechtsblog, 21 February 2020) <https://voelkerrechtsblog.org/and-the-victims-voices/> accessed 11 April 2020.

144 As the situation was referred to the ICC by Bangladesh under article 14 of the Rome Statute and Myanmar is not a State party, the ICC may only exercise its jurisdiction with regard to crimes committed on the territory or by nationals of a State party, that is, Bangladesh. For now, these crimes constitute the crimes against humanity of deportation, other inhumane acts and persecution on grounds of ethnicity and/or religion. See Rome Statute of the International Criminal Court (adopted 17 July 1998, entered into force 1 July 2002) 2187 UNTS 3 (Rome Statute) arts (1)(d), (k), (h), 12-14; Situation in Bangladesh/Myanmar (Decision on the Authorisation of an Investigation) ICC-01/19 (14 November 2019) <https://www.icc-cpi.int/CourtRecords/CR2019_06955.PDF> accessed 11 April 2020.

145 Rome Statute arts 5, 13(b). 
faces the same obstacles as R2P action under Pillar III, namely the Sino-Russian alliance with Myanmar and their resulting obstruction of any concrete action. ${ }^{146}$

On 11 November 2019 The Gambia filed an application instituting proceedings against Myanmar at the ICJ. ${ }^{147}$ The Gambia asserts that Myanmar violated its erga omnes obligations under the Genocide Convention, namely that it committed genocide through various modes of liability, that it failed to prevent and punish genocide, and that it failed to enact legislation to give effect to the provisions of the Genocide Convention. ${ }^{148}$ While requesting the ICJ to adjudge these matters, it also demanded the ICJ to indicate provisional measures to protect and preserve the Rohingyas' rights under the Genocide Convention. ${ }^{149}$ On 23 January 2020, the ICJ found that there is 'a real and imminent risk of irreparable prejudice to the rights [of the Rohingya] invoked by The Gambia' ${ }^{150}$ In doing so, it ordered Myanmar to prevent the commission of acts of genocide by all actors under its control, direction or influence, ensure the preservation of evidence related to the alleged genocidal acts, and report on all measures it has taken to give effect to the ICJ's Order by 23 May and every 6 months thereafter until the final judgment is rendered by the ICJ. ${ }^{151}$ Despite the binding nature of the measures, its effect will be determined by Myanmar's response. ${ }^{152}$ In April 2020, the President's Office of Myanmar issued three directives to its Ministries, Regions, and States Governments. ${ }^{153}$ The first orders all government personnel not to commit any acts of genocide as enshrined in the Genocide Convention and to report any credible information that such acts have been committed. ${ }^{154}$ The second announces criminal investigations with regard to the events acknowledged in the ICOE Report and further prohibits all government officials from destroying any evidence related thereto. ${ }^{155}$ The third aims at preventing the incitement of hatred and violence and the proliferation of

146 Elliot Higgins, 'Transitional Justice for the Persecution of the Rohingya' (2018) 42 Fordham International Law Journal 101, 119; Kurt Mills, 'R2P and the ICC: At Odds or in Sync?' (2015) 26 Criminal Law Forum 73, 96.

147 Application of the Convention on the Prevention and Punishment of Genocide (The Gambia $v$ Myanmar) (Application Instituting Proceedings and Request for Provisional Measures) (11 November 2019) $<$ https://www.icj-cij.org/files/case-related/178/178-20191111-APP-01-00-EN.pdf> accessed 11 April 2020.

148 ibid [111].

149 ibid [112]-[115].

150 The Gambia v Myanmar (Request for Indication of Provisional Measures) (n 141) [75].

151 ibid [79]-[82].

152 LaGrand Case (Germany v United States of America) (Judgment) [2001] ICJ Rep 466 [102]-[103]; Wes Rist, 'What Does the ICJ Decision on The Gambia v Myanmar Mean?' (2020) 24(2) American Society of International Law <https://www.asil.org/insights/volume/24/issue/2/what-does-icj-decision-gambiav-myanmar-mean> accessed 11 April 2020.

153 A response to an alleged genocide requires more than a few directives. It requires concrete action to alter the course of the century old institutionalization of hatred and discrimination. See Param-Preet Singh, 'Myanmar's Directives not Enough to Protect Rohingya' (Human Rights Watch, 9 April 2020) <https://www.hrw.org/news/2020/04/09/myanmars-directives-not-enough-protect-rohingya-0> accessed 11 April 2020.

154 Khin Latt, 'Republic of the Union of Myanmar Office of the President Directive No 1/2020' (President Directive, Republic of the Union of Myanmar Office of the President 9 April 2020) <https://www.president-office.gov.mm/en/?q=briefing-room/news/2020/04/09/id-10001> accessed 11 April 2020.

155 ibid; Summary ICOE Report n (13). 
hate speech. ${ }^{156}$ How effective these directives are, remains to be seen. ${ }^{157}$ However, as Directive 2/2020 only mentions the crimes enumerated in the ICOE Report, it raises questions with regard to the accountability for sexual violence crimes, as reported in the IIFFMM Report. ${ }^{158}$

\section{Regional Organizations as Respondents}

Adediran argues that regional organizations should be given more attention with regard to responses to atrocities. ${ }^{159}$ Regional organizations have the advantage that they are in closer proximity to the events in terms of how it affects them and their cultural and political understanding of the situation, thereby making a response more legitimate and fostering the necessary political will. ${ }^{160}$ This would also settle concerns with regard to abuse of the $\mathrm{R} 2 \mathrm{P}$, as it would no longer be in the hands of the most powerful actors. ${ }^{161}$ Indeed, cooperation with regional organizations is also foreseen by the WSOD and reiterated by the SG in the Report on Implementing the R2P. ${ }^{162}$ However, Adediran's argument falls short of recognizing the limitation that coercive actions by regional organizations still need authorization from the SC, therefore regional arrangements could not authorize such force but would have to focus on non-coercive measures. ${ }^{163}$

156 Khin Latt, 'Republic of the Union of Myanmar Office of the President Directive No 3/2020' (President Directive, Republic of the Union of Myanmar Office of the President 20 April 2020) <https://www.president-office.gov.mm/en/?q=briefing-room/news/2020/04/21/id-10007> accessed 15 May 2020.

157 Myanmar submitted the first report on the measures it has taken to give effect to the ICJ's Order of 23 January on 22 May. The ICJ does not require the report to be made public, and Myanmar has not made an official statement regarding the report at the time of writing. An official from the Ministry of Foreign Affairs of Myanmar has told a news agency that the report is based on the three directives issued by the President's Office of Myanmar. However, it has been argued that Myanmar has been doing too little to give effect to the ICJ Order of 23 January, as the directives do not give enough explanations on what constitutes genocide and the precise steps that should be taken, and do not address the root causes of the Rohingya crisis. See Global Justice Center, 'Webinar: The ICJ Provisional Measures: Is Myanmar Protecting the Rohingya from Genocide?' (Webinar, $20 \quad$ May 2020) $<$ http://www.globaljusticecenter.net/blog/28-publications/videos/1257-webinar-the-icj-provisionalmeasures-is-myanmar-protecting-the-rohingya-from-genocide $>$ accessed 25 May 2020; International Court of Justice, 'NEWS: On 22 May 2020, Myanmar Submitted the First Report Indicated in the ICJ Order on Provisional Measures of 23 January 2020 in the Case Concerning Application of the Convention on the Prevention and Punishment of the Crime of Genocide (The Gambia v Myanmar)' (Tweet, 25 May 2020) <https://twitter.com/cij_icj/status/1264843908477050880?s=12> accessed 25 May 2020; Kyaw Ye Lynn, 'Myanmar Submits Report to ICJ on Rohingya Genocide' Anadolu Agency (Ankara, 23 May 2020) <https://www.aa.com.tr/en/asia-pacific/myanmar-submits-report-to-icj-onrohingya-genocide/1851784> accessed 23 May 2020.

158 Latt (n 156); Summary ICOE Report (n 12). cf IIFFMM Report.

159 UNGA and UNSC 'Report of the Secretary-General A/65/877-S/2011/393' (27 June 2011) UN Doc A/65/877-S/2011/393 [6]; 461.

160 Adediran (n 129) 468, 471, 473.

161 Often, such concerns focused on notions like the West against the rest and displayed residual unease with imperialism. See Adediran (n 129) 476.

162 UNGA Res 60/1 (24 October 2005) UN Doc A/RES/60/1 (WSOD) [139]; UN Doc A/63/677 [10][11], [22], [30], [49], [51], [57].

163 UN Doc A/63/677 [56]. cf Adediran (n 129) 461. Nonetheless, even non-coercive measures under Pillar III can be effective in ensuring the international community's Responsibility to Protect and its usefulness should not be disregarded. An important illustration is for example Kenya. See UNGA and UNSC 'Report of the Secretary-General A/66/874-S/2012/578' (25 July 2012) UN Doc A/66/874-S/2012/578 [23]. See supra, n 70. 
In the context of Myanmar, the ASEAN has a suitable framework to address the Rohingya issue, for example through its human rights mechanisms. ${ }^{164}$ Nonetheless, this would mean that the ASEAN would have to break ties with its traditional non-interference and sovereignty focused approach, while currently political will to resolve the Rohingya issue and pursue justice is limited. ${ }^{165}$

\section{How Can the Aim of the Responsibility to Protect Be Fulfilled After All?}

The aim of the R2P is to protect all populations from atrocity crimes. In the context of Myanmar, too little is currently being done to halt the atrocities committed by the State against its Rohingya minority. Critics of the doctrine argue that this is evidence of its ineffectiveness and irrelevance. ${ }^{166} \mathrm{It}$ is, therefore, necessary to address the following questions: how would the framework of the R2P have to be amended for it to serve its intended function in a situation like Myanmar? Where does the problem lie, is it within the SC set-up or due to the lack of political will?

\section{A. Accepting the Responsibility to Protect's Limitations}

The R2P needs to be recognized as what it is: a tool of moral and political influence. It is a framework under which States can act and have a predetermined set of responses at their disposal. If it is recognized as such, one can observe its usefulness without pointing to apparent shortcomings of public international law. It should not be seen as a law that does not achieve its goal but rather as a doctrine which has changed the world significantly already and which can continue to be used for great causes. Although current shortcomings in its application can inevitably be blamed on the States' lack of political will and the SC veto system, the political reality of world politics will not change. The current soft law status of the doctrine and the fact that it is seen as a right to intervene rather than a duty gives States considerable leeway in the application of the R2P. Therefore, increased application of the R2P should be sought by naming and shaming States that fail to act in accordance with it, while stressing that the R2P can be used as a moral and political tool. Ultimately, this might lead the R2P to become (emerging) CIL. Accordingly, it is not necessary to amend the R2P framework, but rather to advocate its use. Adopting the words of former SG Ban Ki-moon, the R2P should be understood as a 'responsibility to try' to protect populations. ${ }^{167}$

${ }^{164}$ Khan (n 125) 27; Yukiko Nishikawa, 'The Reality of Protecting the Rohingya: An Inherent Limitation of the Responsibility to Protect' (2020) 16 Asian Security 90, 110.

165 Barber (n 134) 567; Khan (n 125) 27; Nishikawa (n 164) 97. Nevertheless, some regional powers have shown support. See supra, $\mathrm{n} 48$.

166 Alex de Waal, 'Darfur and the Failure of the Responsibility to Protect' (2007) 83 International Affairs 1039, 1039-1054; Alex J Bellamy and Edward C Luck, The Responsibility to Protect: From Promise to Practice (Polity Press 2019) 66; Nicole Deitelhoff, 'Is the R2P Failing? The Controversies about Norm Justification and Norm Application of the Responsibility to Protect' (2019) 11 Global Responsibility to Protect 149, 150.

167 UN, 'Secretary-General Defends, Clarifies 'Responsibility to Protect' at Berlin Event on 'Responsible Sovereignty: International Cooperation for a Changed World" (Press Release, UN 15 July 2008) (SG Berlin Speech). 


\section{B. Potential Measures Under the Responsibility to Protect Framework to Be Employed in Myanmar}

Peaceful measures to protect a population from atrocities can be employed by various actors without SC authorization. ${ }^{168}$ However, I have argued above that Myanmar is manifestly failing in its R2P and therefore collective measures are necessary. ${ }^{169}$ The ultimate goal is to protect the Rohingya, and therefore this section addresses various measures which can realistically be implemented in light of the SC's inaction. In any case, there needs to be a shift by the international community from calling on Myanmar to accept its R2P, to assuming the international community's responsibility and acting upon it.

Firstly, smart sanctions aimed at the political and military elite of Myanmar could be employed. ${ }^{170}$ These may include travel bans, restrictions on arms and other equipment, or sanctions aimed at financial transfers of the elite and their families. ${ }^{171}$ They would limit Myanmar's ability to interact with other States, which can then have a positive long-term effect on the political climate within Myanmar. ${ }^{172}$ However, to ensure the effectiveness of sanctions, they should be closely monitored by the international community itself as well as independent stakeholders. ${ }^{173}$ Timing is crucial, as it can take some time before sanctions are felt. ${ }^{174}$ Finally, there may be collateral economic damage for neighbouring countries, which is why close cooperation with these is desirable. ${ }^{175}$ While some States already have implemented targeted sanctions against Myanmar, a more holistic approach should be taken by the international community, including important partners of Myanmar such as China, Russia, or India. ${ }^{176}$

Secondly, international criminal justice may complement and reinforce economic sanctions, as its aim is to end violence and hold accountable those at the top. ${ }^{177}$ This is especially valuable for promoting long-term changes within Myanmar. ${ }^{178}$ Nevertheless, its effectiveness during a crisis is contested, as some argue that criminal prosecutions might undermine a peace process. ${ }^{179}$

168 UNGA Res 60/1 (24 October 2005) UN Doc A/RES/60/1 (WSOD) [139]; UNGA and UNSC 'Report of the Secretary-General A/66/874-S/2012/578' (25 July 2012) UN Doc A/66/874-S/2012/578 [31].

169 Such action can be authorized by the SC, regional organizations with prior SC authorization or the GA can recommend measures under a Uniting for Peace procedure. See UNGA 'Report of the SecretaryGeneral 63/677' (12 January 2009) UN Doc A/63/677 [56].

170 Caroline Fehl, 'Probing the Responsibility to Protect's Civilian Dimension: What Can Non-Military Sanctions Achieve?' in Daniel Fiott and Joachim Koops (eds), The Responsibility to Protect and the Third Pillar (Palgrave Macmillan 2015) 43.

171 Such sanctions can be recommended by the GA under a Uniting for Peace Resolution, in line with the rules on countermeasures. See Case Concerning the Gabcikovo-Nagymaros Project (Hungary $v$ Slovakia) (Judgment) [1997] ICJ Rep 7 [83]-[85]; UN Doc A/63/677 [57]; UNGA and UNSC 'Report of the Secretary-General A/65/877-S/2011/393' (27 June 2011) UN Doc A/65/877-S/2011/393 [36]; Patrick M Butchard, The Responsibility to Protect and the Failures of the United Nations Security Council (Hart 2020) 203-204, 266-268; ICISS, The Responsibility to Protect: Report of the International Commission on Intervention and State Sovereignty (International Development Research Centre 2001) 30.

172 Fehl (n 170) 50, 52; ICISS (n 171) 29.

173 UN Doc A/66/874-S/2012/578 [31]; ICISS (n 171) 30.

174 UN Doc A/65/877-S/2011/393 [36].

175 ibid.

176 See supra, n 49.

177 UN Doc A/65/877-S/2011/393 [37]; UN Doc A/66/874-S/2012/578 [29]; Fehl (n 170) 47.

178 Fehl (n 170) 52.

179 ibid 47-48, 53; Catherine Renshaw, 'Myanmar's Transition without Justice' (2020) Journal of Current Southeast Asian Studies <https://journals.sagepub.com/doi/full/10.1177/1868103419893527> accessed 15 April 2020, 17. 
Thirdly, in The Gambia v Myanmar the ICJ ordered Myanmar to adopt provisional measures to protect the Rohingya. ${ }^{180}$ Ultimately, if found guilty, Myanmar will face State responsibility, which presents an important step towards justice for the Rohingya.

To generate the will of States to act, especially in the context of the GA, but also the ASEAN in this case, various actors play an important role. The SG has an ideal position to instigate a response, thanks to his proximity to governments and the media and his regular interaction with the SC. ${ }^{181}$ Additionally, non-governmental organizations (NGOs) and the media are well suited to advocate on behalf of the Rohingya. ${ }^{182}$ Moreover, States can 'name and shame' Myanmar, the SC, and the GA for their failure to protect, and demand action. ${ }^{183}$ Finally, civil societies and the UN human rights bodies can create public pressure and increase political will by advocating specific responses. ${ }^{184}$

\section{Conclusion}

The brutal legacy of the twentieth century prompted the international community to adopt the R2P. Yet, this doctrine has to date not been utilized to respond to the atrocities in northern Rakhine, in Myanmar. This leaves one to wonder to what extent the doctrine may be used to protect the Rohingya minorities from the horrible atrocities committed against them.

While Pillar I and II are hardly contested, precisely because they do not alter the status quo, Pillar III action is controversial. States have made it clear that its application may in no case encompass regime change, and that the R2P is merely a moral norm, to which they are not legally bound. Regardless, the international community must not ignore the warning signs, instead, it must do its part in protecting populations from atrocity crimes. The R2P was adopted to prevent situations like in Myanmar, it presents the international community with a variety of tools, both peaceful and non-peaceful to halt the atrocities. Although the cases at the ICC and ICJ play an important part in ensuring justice is served and the relevant people and entities are held accountable for their actions, they are not as effective in ending the atrocities right now. I, therefore, propose the R2P be advocated and used in the situation of Myanmar.

Considering a situation where officials in Myanmar seem determined to commit mass atrocities against the Rohingya, measures under Pillar I and II, which require the national authorities' cooperation, are inadequate. However, Pillar III envisages a range of responses, both non-coercive under Chapter VI or VIII and coercive under Chapter VII of the UN Charter, with the authorization of the SC. Contrary to what some critics argue, the R2P does not need to be further operationalized or altered, it rests on well-established principles of international law and is fully functional within the UN Charter framework. Unfortunately, the Sino-Russian political interests and the US's, France's and the UK's lack of interest, dictate the SC's unresponsiveness. Nevertheless, a residual responsibility remains with the GA, which may adopt recommendations under the Uniting for Peace procedure. As the SC is unlikely to alter its approach in the current political climate, and the ASEAN, a regional organization similarly fit to adopt appropriate non-coercive measures, is taking a passive stance, GA recommendations are necessary to protect the

\footnotetext{
180 See supra, n 157.

181 ICISS (n 171) 72-73.

182 ibid 73-74.

183 UN Doc A/66/874-S/2012/578 [41].

184 ibid [45]; Jared Genser, 'The UN Security Council's Implementation of the Responsibility to Protect: A Review of Past Interventions and Recommendations for Improvement' (Policy Brief, Global Centre for the Responsibility to Protect 2018) <http://responsibilitytoprotect.org/files/un-security-councilapplication-of-r2p-jared-genser.pdf $>$ accessed 26 March 2020, 5.
} 
Rohingya. Therefore, the GA should recommend sanctions against Myanmar's elite, and insist on collective action, not merely statements, by the international community.

This can be achieved through advocacy for the doctrine. The R2P's soft law status and the fact that there is no duty for States to intervene are not limitations, but opportunities. While international law can be challenging to enforce, a doctrine, precisely because of its moral character, might have the power to bring about change. Advocacy for the doctrine will put pressure to act on States wanting to bolster their image, as well as on the GA and perhaps even the SC, and thereby require Myanmar to adopt changes in its institutionalized discrimination.

'We can, and must, do better. Humanity expects it and history demands it' ${ }^{185}$ Thus, after proposing various solutions to the Rohingya crisis, it is worth considering taking the road less travelled, because it indeed may make all the difference. 